\section{(2) OPEN ACCESS}

\title{
Marked increase of interferon- $\beta$ after BNT162b2 mRNA vaccination: a case of polyarthritis with pleurisy
}

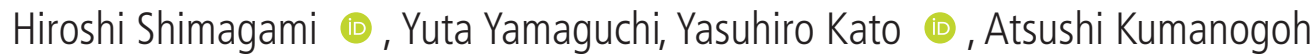

Department of Respiratory Medicine and Clinical Immunology, Graduate School of Medicine, Osaka University, Suita, Osaka, Japan

\section{Correspondence to Dr Yasuhiro Kato; kato@imed3.med.osaka-u.ac.jp}

Accepted 10 February 2022

\begin{abstract}
SUMMARY
Exacerbation of rheumatic disease after vaccination against SARS-CoV-2 is being reported. However, there are only a few cases of new-onset rheumatic diseases. We present two cases of new-onset persistent polyarthritis that developed in patients after receiving the mRNA vaccine against SARS-CoV-2. One patient had bilateral pleural effusions with markedly elevated serum interferon (IFN)- $\beta$, while the other had no effusion, with serum IFN- $\beta$ comparable with that in healthy subjects. Other cytokines were unaltered in association with effusion. Both patients responded well to treatment with $20 \mathrm{mg}$ prednisolone. Although more investigations are needed, the marked increase in serum IFN- $\beta$ levels observed in the case with pleural effusion may reflect an excessive response from the innate immune system to mRNA vaccines.
\end{abstract}

\section{BACKGROUND}

As vaccination against SARS-CoV-2 progresses worldwide, it has become apparent that subjective symptoms exacerbate in approximately $10 \%$ of patients with rheumatic diseases within 2 weeks after vaccination. ${ }^{1}$ However, there are only a few cases of new onset of rheumatic diseases after vaccination against SARS-CoV-2. ${ }^{3}$ Furthermore, the serum cytokine profiles of these patients are scarcely explored.

Here, we present two cases of new-onset persistent polyarthritis after receiving the mRNA vaccine against SARS-CoV-2. One patient had bilateral pleural effusions with markedly elevated serum interferon (IFN)- $\beta$. The other patient had no effusion, and serum IFN- $\beta$ was comparable with that in healthy subjects.

\section{CASE PRESENTATION}

Case 1 was a woman in her 90s without a significant medical history. She was admitted to the previous hospital for pain in her extremities and chest. She had no symptoms after the first dose of the BNT162b2 vaccine. However, she developed severe pain in her extremities and chest the day after the second dose, received 3 weeks following the first dose. After a month of hospitalisation, including antibiotic treatment, her symptoms did not improve, and she was subsequently transferred to our hospital. On admission to our hospital, she had bilateral tenderness in the shoulder, knee and wrist joints. Laboratory results revealed markedly elevated $\mathrm{C}$ reactive protein (CRP) levels and positive rheumatoid factor; however, other disease-specific autoantibodies were negative (table 1).

Musculoskeletal ultrasonography showed tenosynovitis of the long head tendon of the biceps brachii (LHB). On chest X-ray in the sitting position and CT scan, both right and left pleural effusions were up to the level of the anterior margin of the fifth rib (figure 1A,B). Laboratory tests of the pleural fluid showed an increased cell count, predominantly consisting of mononuclear cells. According to Light's criteria, it was an exudative pleural effusion (table 2). Echocardiography showed no pericardial effusion and no findings suggestive of congestive heart failure. Conventional screening ruled out malignant or infectious lesions. Prednisolone $20 \mathrm{mg} /$ day $(0.5 \mathrm{mg} / \mathrm{kg} /$ day $)$ dramatically improved pleural effusion and arthritis.

Case 2 was a man in his 70 s with a history of myocardial and cerebral infarction but no history of arthritis. He developed severe, persistent pain in both shoulders and the lateral side of the thighs a day after the first dose of the BNT162b2 vaccine. A day after receiving the second dose (3 weeks after dose 1 ), his symptoms significantly worsened and lasted for more than a month. There was tenderness in both shoulders and greater trochanters, and the dorsum of his hands was swollen and stiff. Laboratory tests revealed elevated CRP levels; however, all the autoantibodies were negative (table 1). Musculoskeletal ultrasonography showed tenosynovitis of the LHB on both sides, polyarthritis of the fingers and hands, and fluid accumulation in the greater trochanteric bursae. Chest X-ray showed no pleural effusion. Conventional screening ruled out malignant or infectious lesions. His symptoms markedly improved with prednisolone at a dose of $20 \mathrm{mg} /$ day $(0.3 \mathrm{mg} / \mathrm{kg} /$ day $)$.

\section{INVESTIGATIONS}

We measured serum cytokines, interleukin (IL)$1 \beta$, IL- 6 , tumour necrosis factor- $\alpha$, IFN- $\alpha 2$, IFN- $\beta$ and IFN- $\gamma$ levels in the patients during admission to our hospital. Data from healthy subjects and patients with COVID-19 were used as controls. Serum IFN- $\beta$ levels were markedly elevated in case 1 (the patient with pleural effusion) but not in case 2 (the patient without pleural effusion) and patients with COVID-19 (figure 2). Other cytokines were unaltered in association with effusion. These results indicate an association between pleural effusion after mRNA vaccination and IFN- $\beta$. 


\begin{tabular}{llll}
\hline Table 1 & The results of blood examination in case 1 and case 2 \\
\hline Laboratory results of blood & Patient 1 & Patient 2 & Reference range \\
\hline Lactate dehydrogenase, U/L & 187 & 187 & $124-222$ \\
\hline Blood urea nitrogen, $\mathrm{mg} / \mathrm{dL}$ & 19 & 20 & $7-22$ \\
\hline Creatinine, $\mathrm{mg} / \mathrm{dL}$ & 0.49 & 0.86 & $0.5-0.9$ \\
\hline Albumin, g/dL & 1.8 & 3.3 & $3.6-4.7$ \\
\hline C reactive protein, $\mathrm{mg} / \mathrm{L}$ & 167 & 37 & $0-2.0$ \\
\hline Brain natriuretic peptide, pg/mL & 70.4 & $\mathrm{n} / \mathrm{a}$ & $<40$ \\
\hline Thyroid-stimulating hormone, $\mu \mathrm{IU} / \mathrm{mL}$ & 8 & $\mathrm{n} / \mathrm{a}$ & $0.61-4.23$ \\
\hline Free T4, ng/dL & 1.4 & $\mathrm{n} / \mathrm{a}$ & $0.8-1.7$ \\
\hline C3, mg/dL & 87 & $\mathrm{n} / \mathrm{a}$ & $86-160$ \\
\hline C4, mg/dL & 23 & $\mathrm{n} / \mathrm{a}$ & $17-45$ \\
\hline Matrix metalloproteinase-3, ng/mL & 168 & 316 & $37-121$ \\
\hline Sedimentation rate, $\mathrm{mm} / \mathrm{hour}$ & 73 & 69 & $5-19$ \\
\hline Rheumatoid factor, IU/mL & 58 & $<10$ & $0-10$ \\
\hline Anti-CCP antibody, U/mL & $<0.6$ & $<0.6$ & $<4.5$ \\
\hline Antinuclear antibody titre & $1: 40$ & $<40$ & $<40$ \\
\hline Anti-DNA antibody, IU/mL & $<2.0$ & $\mathrm{n} / \mathrm{a}$ & $0-6$ \\
\hline Anti-Smith antibody, U/mL & $<1.0$ & $\mathrm{n} / \mathrm{a}$ & $<10$ \\
\hline Anti-RNP antibody, U/mL & $<2.0$ & $\mathrm{n} / \mathrm{a}$ & $<10$ \\
\hline Anti-Ro/SS-A antibody, U/mL & $<1.0$ & $<1.0$ & $<10$ \\
\hline Anti-La/SS-B antibody, U/mL & 3.5 & $<1.0$ & $<10$ \\
\hline MPO-ANCA, U/mL & $<1.0$ & $<1.0$ & $<3.5$ \\
\hline PR3-ANCA, U/mL & $<1.0$ & $<1.0$ & $<3.5$ \\
\hline & & & \\
\hline
\end{tabular}

\section{DIFFERENTIAL DIAGNOSIS}

In addition to an immune-mediated phenomenon, the differential diagnosis of pleurisy in case 1 included bacterial, mycobacterial, viral or carcinomatous pleurisy, and heart failure. Although there is a high prevalence of tuberculosis in Japan, tuberculous pleurisy was ruled out because adenosine deaminase in the pleural fluid was not significantly elevated, and PCR tests for tuberculosis and mycobacterial cultures of the pleural fluid were negative (table 2). Bacterial pleurisy was also ruled out as empirical therapy was ineffective and bacterial culture of the pleural fluid was negative. Viral pleurisy was considered unlikely given the course of her symptoms, which persisted for over a month. Negative pleural fluid cytology and no evidence of malignancy on CT scan ruled out carcinomatous pleurisy. The possibility of pleural effusion due to heart failure was investigated by performing the following tests: the 12-lead ECG showed sinus rhythm and no significant ST-T changes. Transthoracic echocardiography showed an ejection fraction of 77\%, E/e' of 11.2 and tricuspid regurgitation pressure gradient of $22 \mathrm{~mm} \mathrm{Hg}$ without inferior vena cava dilatation or pericardial effusion, ruling out a pleural effusion due to heart failure.

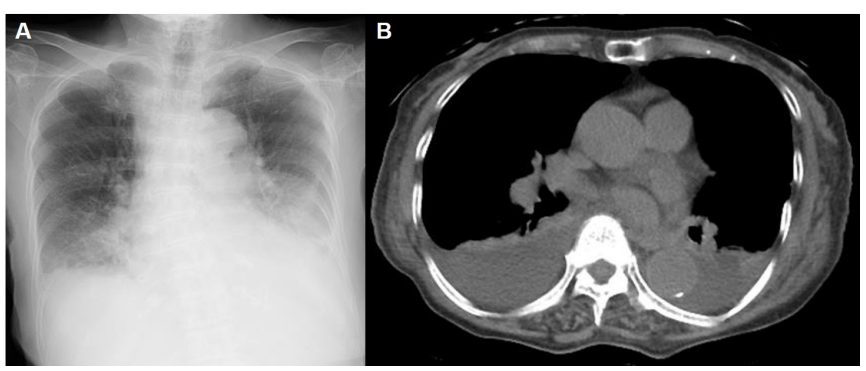

Figure 1 Pleural effusion after mRNA vaccination in case 1. Chest $\mathrm{X}$-ray (A) and chest CT (B) showed bilateral pleural effusions.
Table 2 The laboratory results of pleural fluid in case 1

\begin{tabular}{ll}
\hline Laboratory results of pleural fluid & Patient 1 \\
\hline Cell count, / $\mathrm{LL}$ & 3732 \\
Mononuclear cell count, / $\mathrm{L}$ & 2173 \\
Polymorphonuclear cell count, / $\mathrm{L}$ & 1559 \\
Lactate dehydrogenase, $\mathrm{U} / \mathrm{L}$ & 145 \\
Albumin, $\mathrm{g} / \mathrm{dL}$ & 0.9 \\
Glucose, $\mathrm{mg} / \mathrm{dL}$ & 144 \\
Adenosine deaminase, IU/L & 27 \\
Mycobacterium tuberculosis PCR & Negative \\
\hline
\end{tabular}

Concerning the musculoskeletal symptoms in case 1 and case 2 , the differential diagnosis included paraneoplastic syndromes and infections, in addition to the immune-mediated phenomenon. In both cases, paraneoplastic syndromes were ruled out because contrast-enhanced CT scan from the neck to the pelvic region and upper gastrointestinal endoscopy showed no malignancy, and two faecal immunochemical tests for haemoglobin were negative. Infectious arthritis was also excluded because of negative blood and urine cultures and the absence of valvular vegetations on transthoracic echocardiography, which indicate infectious endocarditis.

Although it was difficult to exclude rheumatic diseases in cases 1 and 2 completely, the symptoms were considered to be related to the mRNA vaccination because neither case met the criteria for classification such as systemic lupus erythematosus or rheumatoid arthritis, ${ }^{45}$ and both were asymptomatic until vaccine administration.

Based on the above findings, the symptoms in case 1 and case 2 were attributed to an immune response to mRNA vaccination.

\section{DISCUSSION}

This report highlights a markedly higher serum IFN- $\beta$ level in a patient who developed pleural effusion and arthritis after mRNA vaccination against SARS-CoV-2. Nucleic acids, including
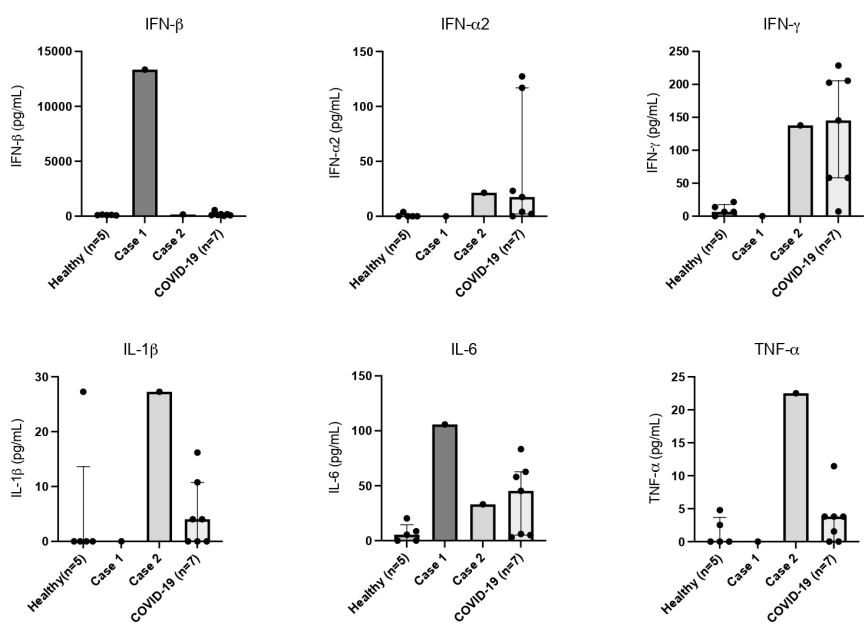

Figure 2 Cytokine profile at the onset of adverse events associated with BNT162b2 vaccination. The graphs show serum cytokine levels of case 1 , case 2 , healthy subjects and patients with COVID-19, determined using a bead-based immunoassay (LEGENDplex Human Anti-Virus Response Panel (13-plex), BioLegend, San Diego, California, USA). In each panel, the values of healthy subjects and patients with COVID-19 indicate the median and the 75th percentile (upper) and 25th percentile (lower). IFN, interferon; IL, interleukin; TNF, tumour necrosis factor. 
mRNA, can induce type I IFN through innate immune system receptors, such as Toll-like receptors. ${ }^{67}$ Although a causal relationship has not been established between mRNA vaccines and pleural effusion and further research is needed, the marked increase in serum IFN- $\beta$ level observed in case 1 (with pleural effusion) may reflect an excessive response of the innate immune system to the mRNA vaccine.

\section{Learning points}

- The RNA vaccine, BNT162b2, rarely causes persistent polyarthritis and pleurisy.

- Prednisolone $20 \mathrm{mg} /$ day could dramatically improve the pleural effusion and arthritis after mRNA vaccination.

- Although the causal relationship has not been established between mRNA vaccines and pleural effusion and further research is required, the marked increase in serum interferon- $\beta$ levels associated with pleural effusion may reflect an excessive response of the innate immune system to the mRNA vaccine.

Acknowledgements The authors would like to extend their gratitude toward all participants in this research.

Contributors HS, YY, YK and AK contributed to the acquisition, analysis and interpretation of the data, and drafting of the manuscript.

Funding This study was funded by the Cloud founding of Peace Winds Japan, Japan Agency for Medical Research and Development (AMED) (JP20fk0108265).

Competing interests None declared.

Patient consent for publication Obtained.

Provenance and peer review Not commissioned; externally peer reviewed.
Open access This is an open access article distributed in accordance with the Creative Commons Attribution Non Commercial (CC BY-NC 4.0) license, which permits others to distribute, remix, adapt, build upon this work non-commercially, and license their derivative works on different terms, provided the original work is properly cited and the use is non-commercial. See: http://creativecommons.org/ licenses/by-nc/4.0/

Case reports provide a valuable learning resource for the scientific community and can indicate areas of interest for future research. They should not be used in isolation to guide treatment choices or public health policy.

\section{ORCID iDs}

Hiroshi Shimagami http://orcid.org/0000-0001-7820-364X

Yasuhiro Kato http://orcid.org/0000-0002-4050-2350

\section{REFERENCES}

1 Barbhaiya M, Levine JM, Bykerk VP, et al. Systemic rheumatic disease flares after SARSCoV-2 vaccination among rheumatology outpatients in New York City. Ann Rheum Dis 2021;80:1352-4.

2 Watad A, De Marco G, Mahajna $\mathrm{H}$, et al. Immune-mediated disease flares or newonset disease in 27 subjects following mRNA/DNA SARS-CoV-2 vaccination. Vaccines 2021:9:435.

3 Quattrini L, Verardi L, Caldarola G, et al. New onset of remitting seronegative symmetrical synovitis with pitting oedema and palmoplantar psoriasis flare-up after Sars-Cov-2 vaccination. J Eur Acad Dermato/ Venereol 2021;35:e727-9.

4 Aringer M, Costenbader K, Daikh D. European League against Rheumatism/American College of rheumatology classification criteria for systemic lupus erythematosus. Ann Rheum Dis 2019;2019:1151-9.

5 Aletaha D, Neogi T, Silma AJ. Rheumatoid arthritis classification criteria: an American College of Rheumatology/European League against rheumatism collaborative initiative. Ann Rheum Dis 2010:2010:1580-8.

6 Kawai T, Akira S. Innate immune recognition of viral infection. Nat Immunol 2006; 7:131-7.

7 Roelofs MF, Wenink MH, Brentano F, et al. Type I interferons might form the link between Toll-like receptor (TLR) 3/7 and TLR4-mediated synovial inflammation in rheumatoid arthritis (rA). Ann Rheum Dis 2009:68:1486-93.

Copyright 2022 BMJ Publishing Group. All rights reserved. For permission to reuse any of this content visit

https://www.bmj.com/company/products-services/rights-and-licensing/permissions/

BMJ Case Report Fellows may re-use this article for personal use and teaching without any further permission.

Become a Fellow of BMJ Case Reports today and you can:

- Submit as many cases as you like

- Enjoy fast sympathetic peer review and rapid publication of accepted articles

- Access all the published articles

- Re-use any of the published material for personal use and teaching without further permission

Customer Service

If you have any further queries about your subscription, please contact our customer services team on +44 (0) 2071111105 or via email at support@bmj.com.

Visit casereports.bmj.com for more articles like this and to become a Fellow 